\title{
Actuaciones en conmemoración del Cincuentenario de la muerte de Domingo Faustino Sarmiento.
}

A iniciativa del Instituto Cultural Peruano-Argentino, recientemente fundado en nuestra Capital, se realizaron, tanto en Lima como en el resto de la República, diversas actuaciones cívicas y culturales, conmemorando el cincuentenario de la muerte del ilustre educador y hombre público argentino, don Domingo Faustino Sarmiento.

Nuestra Facultad se unio fervorosamente a este homenaje al insigne argentino, figura procer cuya fama ha rebasado las fronteras del país natal y cuya gloria honra y enaltece a todo el Continente Americano.

En el Perú, país que se halla vinculado a la Argentina además de por los lazos de historia, raza, idioma y tradición, por una auténtica, recíproca y siempre creciente simpatía, esa conmemoración tenía que adquirir los magnífcos caracteres que tuvo.

"Letras" como un homenaje al gran educador, a quien siempre hemos sentido como nuestro, publica en este número los discursos pronunciados por el doctor Horacio $\mathrm{H}$. Urteaga, Decano de la Facultad, por el doctor Pedro Dulanto, Catedrático de Historia de América, y por el Excelen- 
tísimo señor doctor Eduardo Colombres Mármol, Embajador de la República Argentina, en la brillante e inolvidable actuación que se llevara a cabo el iz de setiembre del presente, en el Salón de Actos de la Facultad, actuación a la cual asistieron: el representante del señor Presidente de la República, General de División Oscar R. Benavides, el señor Ministro de Educación, General Ernesto Montagne, el señor Ministro de Relaciones Exteriores, doctor Carlos Concha, el señor Ministro de Justicia, doctor Diómedes Arias Schreiber, los representantes diplomáticos de las naciones americanas, el Rector de la Universidad de San Marcos, doctor Alfredo Solf y Muro, los Decanos y profesores de las distintas Facultades y numerosísima y selecta concurrencia que ocupó totalmente el salón.

Insertamos también, en este número, el discurso pronunciado por el doctor Manuel Beltroy, catedrático de nuestra Facultad, y uno de los fundadores del Instituto Cultural Peruano-Argentino, en la ceremonia y desfile escolar que se realizara ante la estatua de Sarmiento, erigida en una hermoza plaza de esta cuidad. de Letras "Jorge Puccinelli Converso» 